UDC 691.5

\title{
Technological approaches to directed structure formation of construction nanocomposites with increased corrosion resistance
}

\author{
Authors: \\ Sinitsin Dmitry Aleksandrovich, \\ Ph.D. in Engineering, Ufa State Petroleum Technological University; Ufa, Bashkortostan Republic, Russia, \\ e-mail: d4013438@yandex.ru; \\ Khalikov Rauf Muzagitovich, \\ Ph.D. in Chemistry, Ufa State Petroleum Technological University; Ufa, Bashkortostan Republic, Russia, \\ e-mail: rauf_khalikov@mail.ru; \\ Bulatov Bulat Galievich, \\ Senior Lecturer, Bashkir State Agrarian University, Ufa, Bashkortostan Republic, Russia, e-mail: bfd82@mail.ru; \\ Galitskov Konstantin Stanislavovich, \\ Ph.D. of Engineering, Samara State Technical University; Samara, Russia, e-mail: ksgal@yandex.ru; \\ Nedoseko Igor Vadimovich, \\ Professor, Ufa State Petroleum Technological University; Ufa, Bashkortostan Republic, Russia, \\ e-mail: nedoseko1964@mail.ru
}

\begin{abstract}
Physico-chemical processes of structure formation in nanocomposite building materials are associated with transformations of binding matrices and reinforcing components. The efficiency of building composites in the designed structures depends on the accurate choice of the source components: nanobinders, fillers (aggregates) and manufacturing technology. Increased corrosion resistance of building materials is provided by optimal selection of nanobinders and fillers, by increased density and treatment of the structure surface with protective coatings.

The manufacturing feasibilities for nanocomposites based on various raw materials, nanobinders (gypsum, cement, bitumen, polymer, etc.), and inclusion of various dispersed phases (nanofillers, natural and technogenic aggregates) expand the variety of building composite materials. The synergistic dynamism of the occurrence of geometrical regularity of nanostructures during the structure formation of binders correctly demonstrates the fractal concept. Fractal nanostructures of binders with a rough surface are formed according to mechanism of diffusion-limited aggregation.
\end{abstract}

Keywords: binders, structure formation, the fractality of the microstructure, gypsum cements, the resistance of concrete.

For citation: Sinitsin D.A., Khalikov R.M., Bulatov B.G., Galitskov K.S., Nedoseko I.V. Technological approaches to directed structure formation of construction nanocomposites with increased corrosion resistance. Nanotehnologii $v$ stroitel'stve $=$ Nanotechnologies in Construction. 2019, Vol. 11, no. 2, pp. 153-164. - DOI: 10.15828/2075-8545-2019-11-2-153-164.

Machine-readable information on CC-licenses (HTML-code) in metadata of the paper

$<$ a rel="license" href="http://creativecommons.org/licenses/by/4.0/"><img alt="Creative Commons License" style="border-width:0" src="https://i.creativecommons.org/l/by/4.0/88x31.png"/></a $><$ br / > span xmlns:dct="http://purl.org/dc/terms/" href="http://purl.org/dc/dcmitype/Text" property="dct:title" rel="dct:type" $>$ Technological approaches to directed structure formation of construction nanocomposites with increased corrosion resistance $</$ span $>$ by $<a$ xmlns:cc="http://creativecommons.org/ns\#" href="Nanotehnologii v stroitel'stve = Nanotechnologies in Construction. 2019, Vol. 11, no. 2, pp. 153-164. - DOI: 10.15828/2075-8545-2019-11-2-153-164." property="cc:attributionName" rel="cc:attributionURL">Sinitsin D.A., Khalikov R.M., Bulatov B.G., Galitskov K.S., Nedoseko I.V. $<$ /a $>$ is licensed under a $<$ a rel="license" href="http://creativecommons.org/licenses/by/4.0/" $>$ Creative Commons Attribution 4.0 International License $</ a>$. $<$ br />Based on a work at <a xmlns:dct="http://purl.org/dc/terms/" href="http://nanobuild.ru/en_EN/nanobuild-2-2019/" rel="dct:source" >http://nanobuild.ru/en_EN/ nanobuild-2-2019/</a $>$. $<$ br $/>$ Permissions beyond the scope of this license may be available at $<$ a xmlns:cc="http://creativecommons.org/ns\#" href="d4013438@ yandex.ru" rel="cc:morePermissions" $>$ d4013438@yandex.ru $</ a>$.

The paper has been received by editors: 30.12 .2018 .

The paper has been received by editors after peer-review: 15.02.2019.

The paper has been accepted for publication: 01.03.2019. 


\section{Технологичные подходы направленного структурообразования нанокомпозитов строительного назначения с повышенной коррозионной устойчивостью}

\section{Авторы:}

Синицин Дмитрий Александрович,

доц. каф. «Строительные конструкции», ФГБОУ ВО «Уфимский государственный нефтяной технический университет»; г. Уфа, Республика Башкортостан, Россия, d4013438@yandex.ru;

\section{Халиков Рауф Музагитович,}

доц. каф. «Строительные конструкции», ФГБОУ ВО «Уфимский государственный нефтяной технический университет»; г. Уфа, Республика Башкортостан, Россия, rauf_khalikov@mail.ru;

\section{Булатов Булат Галиевич,}

ст. преп. каф. « Природообустройства, строительства и гидравлики», ФГБОУ ВО «Башкирский государственный аграрный университет»; г. Уфа, Республика Башкортостан, Россия, bfd82@mail.ru;

Галицков Константин Станиславович,

доц. каф. «Механизация, автоматизация и энергоснабжение строительства», ФГБОУ ВО «Самарский государственный технический университет»; г. Самара, Россия, ksgal@yandex.ru;

\section{Недосеко Игорь Вадимович,}

проф. каф. «Строительные конструкции», ФГБОУ ВО «Уфимский государственный нефтяной технический университет»; г. Уфа, Республика Башкортостан, Россия, nedoseko1964@mail.ru

Резюме: Физико-химические процессы структурообразования в нанокомпозитных стройматериалах сопряжены с трансформациями вяжущих матриц и армирующих компонентов. Работоспособность строительных композитов в проектируемых сооружениях зависит от точного выбора исходных компонентов: нановяжущих, наполнителей (заполнителей) и технологии изготовления. Повышение коррозионной стойкости стройматериалов обеспечивается оптимальным подбором нановяжущих и заполнителей, увеличением плотности и обработкой поверхностного слоя конструкции защитными покрытиями.

Возможности изготовления нанокомпозитов на основе различных сырьевых компонентов: нановяжущих (гипсовых, цементных, битумных, полимерных и т.д.) и включения различных дисперсных фаз (нанонаполнителей, природных и техногенных заполнителей) расширяет разнообразие строительных композиционных материалов. Синергетический динамизм возникновения пространственной упорядоченности наноструктур при структурообразовании вяжущих корректно демонстрирует фрактальная концепция. Фрактальные наноструктуры вяжущих с шероховатой поверхностью образуются по механизму диффузионно-лимитированной агрегации.

Ключевые слова: вяжущие, структурообразование, фрактальность микроструктуры, гипсовые цементы, стойкость бетонов.

Для цитирования: Синицин Д.А., Халиков Р.М., Булатов Б.Г., Галицков К.С., Недосеко И.В. Технологичные подходы направленного структурообразования нанокомпозитов строительного назначения с повышенной коррозионной устойчивостью // Нанотехнологии в строительстве. - 2019. - Том 11, № 2. - С. 153-164. - DOI: 10.15828/2075-8545-2019-11-2-153-164.

Machine-readable information on CC-licenses (HTML-code) in metadata of the paper

$<$ a rel="license" href="http://creativecommons.org/licenses/by/4.0/" $><$ img alt="Creative Commons License" style="border-width:0" src="https://i.creativecommons.org/l/by/4.0/88x31.png" / ></a $><$ br / ><span xmlns:dct="http://purl.org/dc/terms/" href="http://purl.org/dc/dcmitype/Text" property="dct:title" rel="dct:type" $>$ Technological approaches to directed structure formation of construction nanocomposites with increased corrosion resistance $</$ span $>$ by $<$ a xmlns:cc="http://creativecommons.org/ns\#" href="Nanotehnologii v stroitel'stve = Nanotechnologies in Construction. 2019, Vol. 11, no. 2, pp. 153-164. - DOI: 10.15828/2075-8545-2019-11-2-153-164." property="cc:attributionName" rel="cc:attributionURL">Sinitsin D.A., Khalikov R.M., Bulatov B.G., Galitskov K.S., Nedoseko I.V. $</$ a $>$ is licensed under a $<$ a rel="license" href="http://creativecommons.org/licenses/by/4.0/" $>$ Creative Commons Attribution 4.0 International License $</ a>.<$ br />Based on a work at <a xmlns:dct="http://purl.org/dc/terms/" href="http://nanobuild.ru/en_EN/nanobuild-2-2019/" rel="dct:source" >http://nanobuild.ru/en_EN/ nanobuild-2-2019/</a $>.<\mathrm{br} />$ Permissions beyond the scope of this license may be available at $<\mathrm{a}$ xmlns:cc="http://creativecommons.org/ns\#" href="d4013438@ yandex.ru" rel="cc:morePermissions" $>$ d4013438@yandex.ru</a $>$.

Статья поступила в редакцию: 30.12.2018.

Статья поступила в редакцию после рецензирования: 15.02.2019.

Статья принята к публикации: 01.03.2019. 


\section{INTRODUCTION}

To produce high-quality multifunctional binders for construction industry, one needs to control directly formation of nanostructure materials. The effective application of nanocomposite binders in the technology of required building materials is explained mainly by fractionation of the powders of the initial raw materials, by modification with plasticizing nanoadditives.

The purpose of this article is to study the technological processes of structure formation in corrosion-resistant building materials within the framework of the fractal concept.

\section{MAIN PART}

Structural processes run during the entire lifecycle of building materials: from design to the moment of critical decline in performance indicators. Studies concerning creation of nanostructured concretes are among the most promising approaches in nanotechnology for building materials: micro reinforcement, mobility control with modified plasticizers, etc. [1]. The possibilities to design new generation of concrete are based on the use of ultrafine active mineral additives with a high content of noncrystalline silicon dioxide, aluminosilicate metaka- olins and allow production of building materials of high $(55 \div 80 \mathrm{MPa}$ ) and ultrahigh (over $80 \mathrm{MPa}$ ) strength, low permeability, and increased corrosion resistance.

When creating a nanostructured binder, it is necessary to meet some conditions to make nanocomposite perform as a monolithic building material:

- nanocomponents in the composition must be chemically compatible, and the aggregates must have good adhesion with nanobinding matrix;

- combinable components must have close linear thermal expansion coefficients;

- modified nanosize additives should have a direct influence on the formation of microstructure with increased corrosion resistance to damage in corrosive environments.

In the process of directed creation of composite nanomaterials from the corresponding components, one needs to take into account the operational parameters that provide technological production of corrosion-resistant nanocomposites with the required characteristics (Fig. 1):

Similar mechanisms of structure formation (transitions of micro-, meso-, macrostructure) of nanocomposites based on variety of raw materials reflect the spectrum of composite materials used in the construction industry. The diverse building composites make it possible to expand the manufacturing possibilities due to various nano-

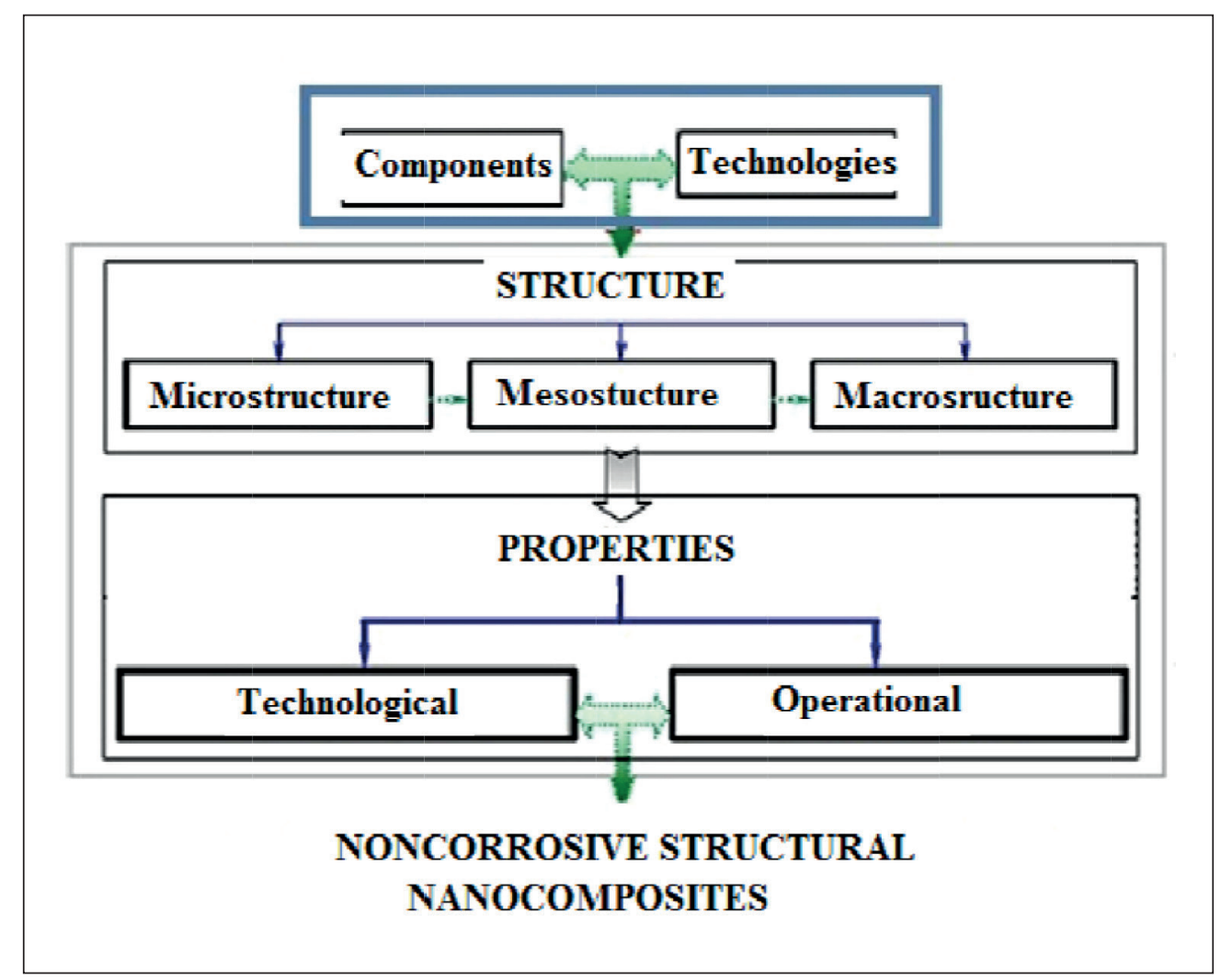

Fig. 1. A set of factors affecting the technology of nanostructured corrosion-resistant materials in construction 
binders (plaster, cement, bitumen, polymer, etc.) and the inclusion of various dispersed phases (fine mineral or polymer powders, coarse aggregates, short or continuous fibers, continuous reinforcement) [2]. The production of nanopowder binding components of raw materials requires automation of control systems technology [3].

Building materials made with nanostructured binders consist of amorphous newgrowths obtained on the basis of the sol - gel junction. For example, calcium silicate hydrogel is formed within hydration of Portland cement. Binders are microheterogeneous fractal systems containing polymer nanoparticles in equilibrium with monomers, polymeric in cation or anion. Hydrogen, donor-acceptor, ion-dipole and other interatomic interactions resulted in connected nanoparticles that form microgels. The use of the fractal concept [4-6] to describe the microstructure of nanostructured building materials, including the technological principles of creating sol-gel nanosystems [7], is considered as a promising research field.

A decrease in the free energy occurs during the interaction of nanoparticles of the dispersed phase through an interlayer of the dispersion medium, as well as in the process of coagulation of the nanofilters. During coagulation of sols, cluster aggregates are obtained, the fractal dimension of which depends on the type of coagulation; for fractal clusters formed under conditions of slow coagulation, the fractal dimension is higher than for nanoaggregates formed under conditions of rapid hardening (setting).

After addition of fillers (aggregates), the adhesive interaction takes place in microstructure of building composite and nanoaggregates are formed, clusters - groups of particles "cemented" by nanobinders; as well as nonaggregated filler microparticles. A sequential modification of the physicochemical topology of the nanostructure runs in the technological process of hydration and hardening of binding agents. In the case when nanoparticles have approximately the same size and shape, the cluster aggregates become larger quickly.

Fractal structures with a rough surface of nanobinding calcium hydrosilicates are formed by the mechanism of diffusion-limited aggregation: a cluster is a colloid particle [8]. Fractal aggregates are formed as a result of polycondensation during adhesion of diffusing colloidal particles, and the size of aluminosilicate binder nanoclusters gradually increases from tens to hundreds of nanometers. The formation of such fractals occurs in non-equilibrium conditions, when the effect of dynamic self-organization dominates (Fig. 2).

The synergistic dynamism of the occurrence of geometrical and temporal regularity of binder nanostructures correctly demonstrates fractal analysis. As applied to binding nanostructures, fractals are self-similar objects with a self-similarity interval from a few tenths of nanometer to hundred nanometers. The aspiration of condensed materials to self-organization into multifractal structures is a fundamental regularity of nanostructured building composites evolution. It has been determined that modern concretes, which are used in the construction of tall building [9], have specified strength due to fractal interactions.

The parameters of structure formation [10] during the hardening of nanobinders in building materials are characterized by fluctuations in the density of microparticles of nanostructures. The process of modifying cement binding systems at the nanoscale level is complicated by the formation of hydrosilicate phases with different crystalline structures that cause a certain disorder in the formed nanostructure. In addition, the processes of recrystallization of hydrates (for example, metastable calcium hydroaluminates) can change the topology of the nanostructure when the hardening conditions (temperature, humidity, etc.) change.

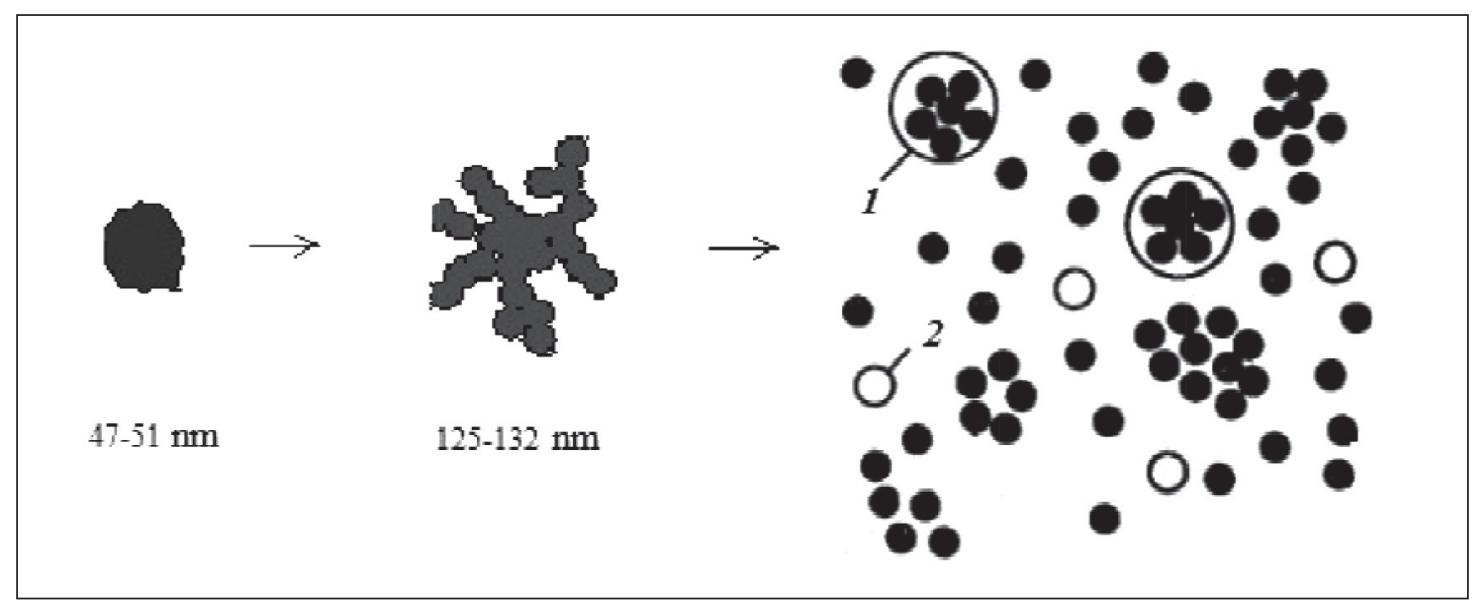

Fig. 2. The scheme of cluster fractal aggregation in nanobinders and interaction with the filler (1 - aggregates of «encapsulated» microparticles; 2 - micropores) 
The cohesive interaction between large and small nanoparticles causes the formation of cluster-type aggregates in the system; and the formed nanoclusters, in turn, can form a fractal nanostructure [11]. In the concrete building materials made of dense fillers, micropores appear due to physical and chemical processes of cement hardening, and also due to evaporation of water. The porosity of heavy structural concrete is $5-7 \%$, and characteristics of concrete microstructure are: the porosity of cement stone (capillary mesopores, gel nanopores), contact zone porosity, filler porosity, intergranular micropores. The article [12] shows that the method to obtain porous materials has a significant impact on the character of formation of material pore structure: changing the technological parameters one can regulate both the total porosity and the nature of the structure of the porous material, for example, micropores smaller than $100 \mathrm{~nm}$ occupy about $85 \%$ of the gas phase of cement stone.

It should be noted that the corrosion destruction of building materials is a process of transfer of aggressive reagent in micropores, accompanied by the dissolution of concrete solid phase. Physico-chemical interaction of concrete cement matrix with aggressive environment is often accompanied by the formation of insoluble compounds. Such solid-phase newgrowths, depositing in pores and capillaries, clog up and mud micropores, that decelerates diffusion of destructive agents deep into building material. By optimal selection of nanostructured cements it is possible to strengthen the processes of self-inhibition of concrete destruction processes and thus to increase the corrosion resistance of products and structures.

The article [13] describes the results of tests of the cement compositions with nanoadditives on the basis of aminoethanethiol. It is shown that the mechanical and water-insulating properties of cement mortar are improved with the introduction of nanoadditives: the bending strength of cement stone after 48-hour curing increases by $15 \%$, and the water - insulating effect-by $60 \%$. Aminoethanethiol nanoadditive increases the degree of dispersion of the newgrowths formed in the process of cement hydration, that increased mechanical strength, degree of clogging and filling of the micropores.

Today composite materials with combined (polymatrix) matrices consisting of two or more different chemical composition of corrosion resistant components have been designed. The fillers are evenly distributed in matrix, they serve as reinforcing components, as they play a major role in increasing the strength and resistance to corrosion [14] of building material. The use of pozzolanic nanoadditives provides filling of the contact zone of nanocomposite concrete with hydration products and reduction of water permeability. High resistance of nanocomposite concretes on the basis of aluminate cements is caused by clogging of micropores of cement stone with aluminate gel.

It should also be noted that the production of building nanomaterials, which is distinguished by the variety and energy intensity of technological equipment used for crushing, grinding, transportation and firing of solid, granular and powdered materials, is a huge source of emission of aerosol pollution into production facilities and the atmosphere. The article [15-17] analyzes sustainable technologies which minimize the negative impact of nanobinding building materials on the environment. Innovative solutions to complex environmental problems should be based on careful monitoring of nanocomposite construction technology.

The development of energy-saving and environmentally friendly technologies requires an increase in the share of recoverable resources, for example, industrial phosphogypsum. The most promising areas of phosphogypsum utilization include its use in the production of gypsum nanobinding materials with the use of pressing technology in combination with various activation methods. The technology of production of small-piece wall and partition products obtained by semi-dry pressing of phosphogypsum compositions and solid residues of soda production is proposed [18]. Phosphogypsum nanocomposite waste production of soda hardens due to complex reactions with the formation of hydrosulfoaluminate and calcium hydrosilicates. With regard to the fractal concept, structure formation in phosphogypsum building materials proceeds in the form of fractal clusters of calcium sulfate dihydrate $\mathrm{CaSO}_{4} \cdot 2 \mathrm{H}_{2} \mathrm{O}$.

Different ways to improve water resistance of gypsum products are based on reducing solubility of gypsum, compaction of gypsum (gypsum concrete) mass, the use of protective coating, etc. Innovative approach to enhance the stability of gypsum composites under conditions of high humidity employs nanoadditives of organosilicon hydrophobizing components. The formation of two- and threedimensional water-repellent surfaces based on silicone macromolecules is correctly described by fractal analysis.

In recent years, modification of concrete structure by means of multifunctional nanoadditives based on superplasticizers [19] and some microcomponents (silica fume, metakaolin, industrial ash, etc.) has been intensively developed. Such nanoadditives, interacting with calcium hydroxide of the nanobinder, provide increased impermeability of the artificial conglomerate and decelerate diffusion of the aggressive reagent deep into the building material. Reduction of destruction of concrete and reinforced concrete structures in aggressive environment (acid, sulphate, etc. destruction) is achieved by introducing anticorrosion nanoadditives [20] and a variety of protective coatings. Stabilization of nanocomposite building materials by such methods is accurately predicted within the framework of the fractal concept. 


\section{CONCLUSION}

Thus, the mechanisms of structure formation of nanocomposites reflect the variety of binders used in the construction industry. During the formation of corrosion-resistant nanocomposite building materials one should apply modern methods of research of fractal dimension. That leads to a significantly improved performance of the materials exposed to aggressive environments.

\section{ВВЕДЕНИЕ}

Для производства качественных многофунциональных вяжущих в строительной индустрии необходимо целенаправленно управлять формированием наноструктуры материалов. Эффективное использование нанокомпозиционных вяжущих в технологии востребованных стройматериалов обусловливается, прежде всего, фракционированием порошков исходных сырьевых компонентов, модифицированием пластифицирующими нанодобавками.

Цель данной статьи - исследование технологических процессов структурообразования в коррозионностойких стройматериалах в рамках фрактальной концепции.

\section{ОСНОВНАЯ ЧАСТЬ}

Структурообразовательные процессы протекают в течение всего «жизненного» цикла стройматериалов: от конструирования до момента критического снижения показателей эксплуатационных характеристик. Работы в области создания наноструктурированных бетонов являются одними из самых перспективных подходов в нанотехнологии строительных материалов: микроармирование, управление подвижностью модифицированными пластификаторами и др. [1]. Возможности конструирования бетонов нового поколения основаны на использовании ультрадисперсных активных минеральных добавок с высоким содержанием некристаллического диоксида кремния, алюмосиликатных метакаолинов и позволяют выпускать стройматериалы высокой $(55 \div 80$ МПа) и сверхвысокой (свыше 80 МПа) прочности, низкой проницаемости, повышенной коррозионной стойкости.

При создании наноструктурированного вяжущего необходимо выполнить ряд условий, чтобы нанокомпозит работал как монолитный стройматериал:

- нанокомпоненты в составе должны быть химически совместимыми, а заполнители должны обладать хорошей адгезией к нановяжущей матрице; - совмещаемые компоненты обязаны иметь близкие коэффициенты линейного температурного расширения;
- модифицированные наноразмерные добавки должны направленно влиять на формирование микроструктуры с повышенной коррозионной устойчивостью к разрушениям в агрессивных средах.

В процессе направленного создания композиционных наноматериалов из соответствующих компонентов необходимо учитывать эксплуатационные параметры, позволяющие технологическое получение коррозионноустойчивых нанокомпозитов с требуемыми характеристиками (рис. 1):

Общность закономерностей структурообразования (переходы микро-, мезо-, макроструктура) нанокомпозитов на базе разнообразных сырьевых компонентов отражает спектр композиционных материалов, применяемых в стройиндустрии. Многообразие строительных композитов позволяет расширить возможности изготовления на основе различных нановяжущих (гипсовых, цементных, битумных, полимерных и т.д.) и включения различных дисперсных фаз (тонкодисперсных минеральных или полимерных порошков, грубодисперсных заполнителей, коротких или непрерывных волокон, непрерывной арматуры) [2]. Производство нанопорошковых вяжущих компонентов исходного сырья требует автоматизацию систем управления технологии [3].

Стройматериалы, изготовленные с помощью наноструктурированных вяжущих, состоят из аморфных новообразований, полученных на базе перехода золь $\leftrightarrow$ гель. Например, при гидратации портландцемента образуется кальциево-силикатный гидрогель. Вяжущие являются микрогетерогенными фрактальными системами, содержащими в равновесии с мономерами полимерные по катиону или аниону наночастицы. Связанные в результате водородных, донорно-акцепторных, ион-дипольных и др. межатомных взаимодействий, эти наночастицы образуют микрогели. Использование фрактальной концепции [4-6] для описания микроструктуры наноструктурированных стройматериалов, в том числе технологические принципы создания золь-гель наносистем [7], считается перспективным направлением.

Уменьшение свободной энергии происходит при взаимодействии наночастиц дисперсной фазы через 


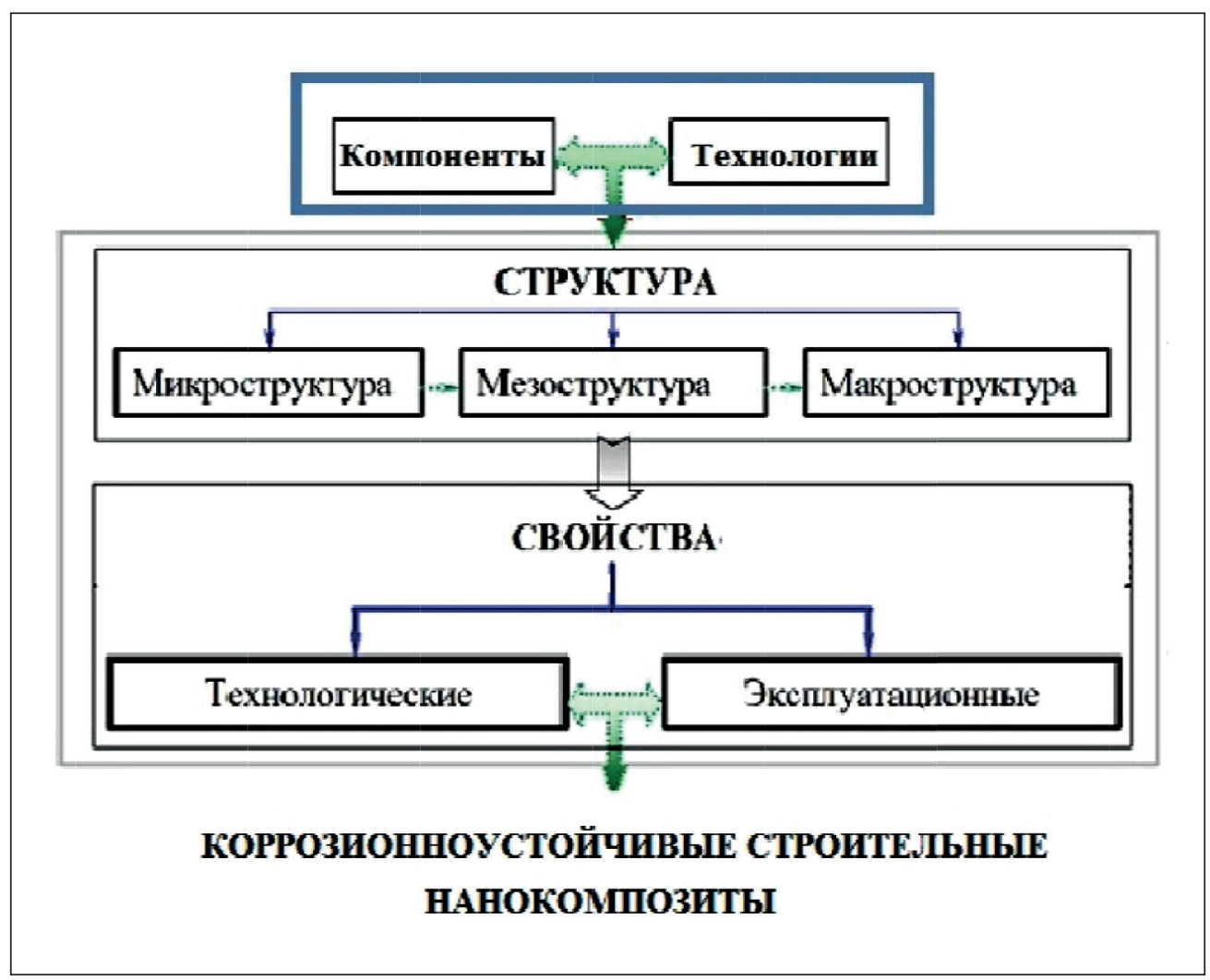

Рис. 1. Разнообразные факторы, влияющие на технологию наноструктурированных коррозионностойких материалов в строительной индустрии

прослойку дисперсионной среды, а также в процессе коагуляции нановяжущих. При коагуляции золей получаются кластерные агрегаты, фрактальная размерность которых зависит от типа коагуляции; для фрактальных кластеров, образующихся в условиях медленной коагуляции, фрактальная размерность оказывается выше, чем для наноагрегатов, формирующихся в условиях быстрого твердения (схватывания).

В микроструктуре строительного композита после добавления наполнителей (заполнителей) происходит адгезионное взаимодействие и формируются наноагрегаты, кластеры - группы частиц, «цементированных» наносвязующим; а также неагрегированные микрочастицы наполнителей. В технологическом процессе гидратации и твердения нановяжущих происходит последовательная модификация физико-химической топологии наноструктуры. В случае, когда наночастицы имеют приближенно одинаковые размеры и форму, кластерные агрегаты укрупняются достаточно быстро.

Фрактальные структуры с шероховатой поверхностью нановяжущих гидросиликатов кальция сформируются по механизму диффузионно-лимитированной агрегации: кластер - коллоидная частица
[8]. Фрактальные агрегаты образуются в результате поликонденсации при слипании диффундирующих коллоидных частиц, при этом постепенно увеличивается размер нанокластеров алюмосиликатных вяжущих от десятков до сотен нанометров. Формирование таких фракталов происходит в неравновесных условиях, когда доминирует эффект динамической самоорганизации (рис. 2).

Синергетический динамизм возникновения пространственной и временной упорядоченности наноструктур вяжущих корректно демонстрирует фрактальный анализ. Применительно к вяжущим наноструктурам фракталы представляют самоподобные объекты с интервалом самоподобия от нескольких десятых долей нанометра до сотни нанометров. Стремление конденсированных материалов к самоорганизации в мультифрактальные структуры - это фундаментальная закономерность эволюции наноструктурированных строительных композитов. Установлено, что современные бетоны, которые используются в строительстве зданий с повышенной этажностью [9], обладают востребованной прочностью за счет фрактальных взаимодействий.

Параметры структурообразования [10] при твердении нановяжущих в стройматериалах харак- 


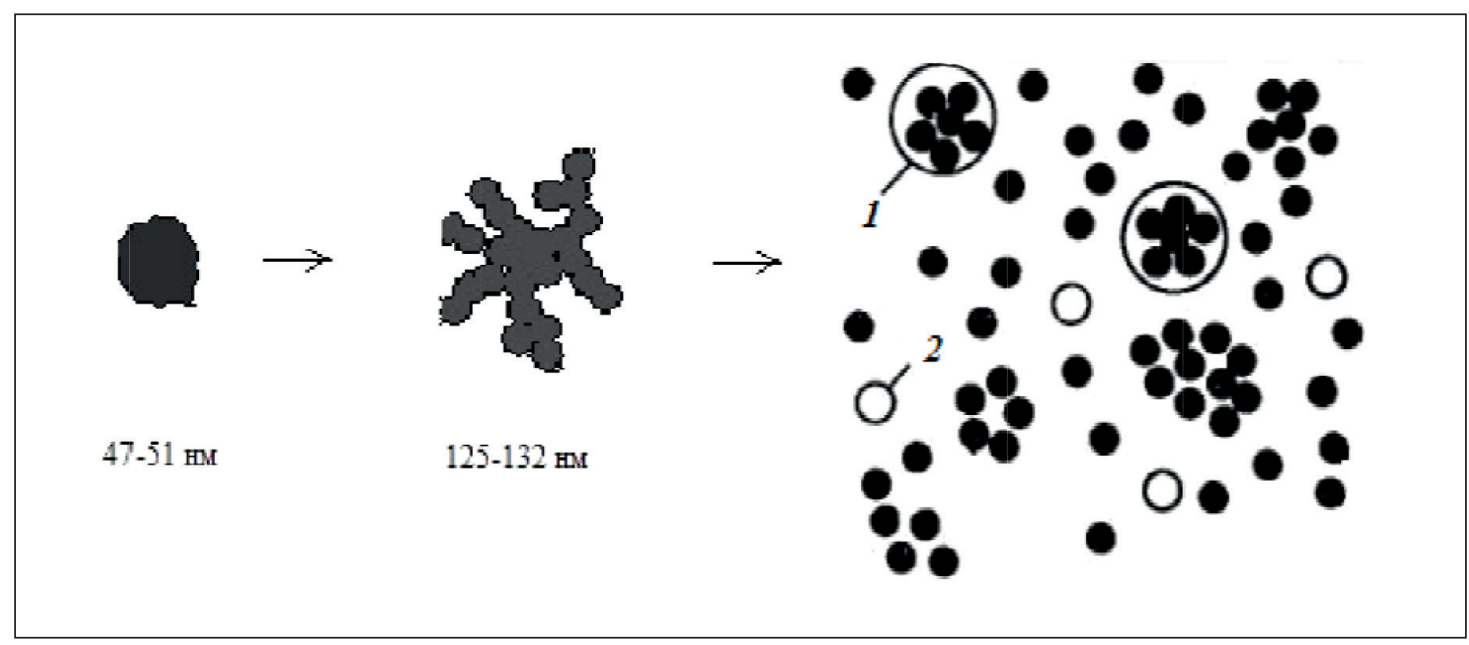

Рис. 2. Схема фрактальной агрегации кластеров в нановяжущих и взаимодействие с наполнителем (1 - агрегаты «закапсулированных» микрочастиц; 2 - микропоры)

теризуются флуктуацией плотности микрочастиц наноструктур. Процесс модифицирования цементных вяжущих систем на наноуровне осложняется формированием гидросиликатных фаз с различным кристаллическим строением, вносящих определенную неупорядоченность в формирующуюся наноструктуру. Кроме того, процессы перекристаллизации гидратов (например, метастабильных гидроалюминатов кальция) могут изменять топологию наноструктуры при изменении условий твердения (температуры, влажности и др.).

Когезионное взаимодействие между крупными и мелкими наночастицами обусловливает формирование в системе агрегатов кластерного типа, а образовавшиеся нанокластеры, в свою очередь, могут образовывать фрактальную наноструктуру [11]. В бетонных стройматериалах, изготовленных на плотных заполнителях, возникновение микропор связано с физико-химическими процессами твердения цемента, а также с испарением воды. Пористость тяжелых конструкционных бетонов составляет 5-7 \%, а характеристиками микроструктуры бетонов служат: пористость цементного камня (капиллярные мезопоры, гелевые нанопоры), пористость контактной зоны, пористость заполнителя, межгрануловые микропоры. В работе [12] показано, что способ получения пористых материалов оказывает значительное влияние на характер формирования поровой структуры материалов: изменяя технологические параметры, можно регулировать как общую пористость, так и характер строения пористого материала, например, микропоры размером менее 100 нм занимают около $85 \%$ газовой фазы цементного камня.

Следует отметить, что коррозионное разрушение стройматериалов представляет собой процесс переноса агрессивного реагента в микропорах, сопровождающийся растворением твердой фазы бетонов. Физико-химическое взаимодействие цементной матрицы бетонов с агрессивной средой часто сопровождается образованием нерастворимых соединений. Такие твердофазные новообразования, откладываясь в порах и капиллярах, закупоривают и кольматируют микропоры, что приводит к замедлению диффузии разрушающих агентов в глубь стройматериала. Путем оптимального подбора наноструктурированных цементов можно усилить процессы самоторможения процессов деструкции бетонов и тем самым повысить коррозионную стойкость изделий и конструкций.

В статье [13] представлены результаты испытаний исследований цементных композиций с нанодобавками на основе аминоэтаксиаэросила. Показано, что механические и водоизолирующие свойства цементного раствора улучшаются при введении нанодобавок: прочность на изгиб цементного камня после 48-часового отверждения увеличивается на $15 \%$, а водоизолирующий эффект - на 60\%. Нанодобавка аминоэтаксиаэросила увеличивает степень дисперсности новообразований, формирующихся в процессе гидратации цемента, что приводит к увеличению механической прочности, степени кольматации и заполнения микропор.

В настоящее время созданы композиционные стройматериалы с комбинированными (полиматричными) матрицами, состоящие из двух и более различных по химическому составу коррозионностойких компонентов. В матрице равномерно распределены наполнители (заполнители), которые выполняют функции армирующих компонентов, так как они играют главную роль в повышении 
прочности и устойчивости к коррозионному разрушению [14] стройматериала. Использование пуццолановых нанодобавок обеспечивает заполнение контактной зоны нанокомпозитных бетонов продуктами гидратации и снижение водопроницаемости. Высокая стойкость нанокомпозиционных бетонов на основе алюминатных цементов обусловлена кольматацией микропор цементного камня алюминатным гелем.

Отметим также, что производство строительных наноматериалов, выделяющееся разнообразием и энергоемкостью технологического оборудования, используемого для дробления, измельчения, транспортировки и обжига твердых, гранулированных и порошкообразных материалов, является достаточно серьезным источником выброса аэрозольных загрязнений в производственные помещения и атмосферу. В работах [15-17] проанализированы рациональные технологии, которые минимизируют негативное воздействие производства нановяжущих стройматериалов на окружающую среду. Инновационные пути решения непростых экологических проблем должны основываться на тщательном мониторинге технологии строительных нанокомпозитов.

Разработка энергоресурсосберегающих и экологически безопасных технологий требует роста доли использования вторичных ресурсов, например, техногенного фосфогипса. К наиболее перспективным направлениям утилизации фосфогипса относится использование его в производстве гипсовых нановяжущих материалов с применением технологии прессования в сочетании с различными методами активации. Предложена технология производства мелкоштучных стеновых и перегородочных изделий, получаемых методом полусухого прессования композиций фосфогипса и твердых остатков содового производства [18]. Фосфогипсовая нанокомпозиция с отходами производства соды твердеет за счет комплексных реакций с образованием гидросульфоалюминатов и гидросиликатов кальция. При рассмотрении с позиции фрактальной концепции структурообразование в фосфогипсовых стройма- териалах происходит в виде фрактальных кластеров дигидрата сульфата кальция $\mathrm{CaSO}_{4} \cdot 2 \mathrm{H}_{2} \mathrm{O}$.

Разнообразные способы повышения водостойкости гипсовых изделий основаны на уменьшении растворимости гипса, уплотнении гипсовой (гипсобетонной) массы, применении защитной обмазки и т.п. Инновационным подходом усиления стабильности гипсовых композитов в условиях повышенной влажности служат нанодобавки кремнийорганических гидрофобизирующих компонентов. Формирование двух- и трехмерных водоотталкивающих поверхностей на базе силиконовых макромолекул достаточно корректно описывается фрактальным анализом.

В последние годы интенсивно развивается направление модифицирования структурообразования бетонов с помощью полифункциональных нанодобавок на основе суперпластификаторов [19] и разнообразных микрокомпонентов (микрокремнезем, метакаолин, техногенная зола и т.п.). Такие нанодобавки, взаимодействуя с гидроксидом кальция нановяжущего, обеспечивают повышенную непроницаемость искусственного конгломерата и замедляют диффузию агрессивного реагента вглубь стройматериала. Уменьшение разрушения бетонных и железобетонных сооружений в агрессивной окружающей среде (кислотная, сульфатная и т.п. деструкция) достигается за счет введения в состав антикоррозийных нанодобавок [20] и разнообразных защитных покрытий. Стабилизация нанокомпозиционных стройматериалов такими методами достаточно точно прогнозируется в рамках фрактальной концепции.

\section{ЗАКЛЮЧЕНИЕ (ВЫВОДЫ)}

Таким образом, закономерности структурообразования нанокомпозитов отражают многообразие вяжущих материалов, применяемых в стройиндустрии. При формировании устойчивых к коррозии нанокомпозиционных стройматериалов следует привлекать современные методы исследования фрактальной размерности и это направленно приводит к существенному улучшению их эксплуатационных характеристик в агрессивных средах. 


\section{REFERENCES}

1. Figovsky O.L., Beilin D.A., Ponomarev A.N. Uspekhi primeneniya nanotekhnologiy v stroitel'nykh materialakh [Successful implementation of nanotechnologies in building materials.] Nanotehnologii v stroitel'stve $=$ Nanotechnologies in Construction, 2012. Vol. 4, no. 3. P. 6-21. (In Russian).

2. Bazhenov Y. M., Chernyshov E. M., Korotkikh D. N. Konstruirovaniye struktur sovremennykh betonov: opredelyayushchiye printsipy i tekhnologicheskiye platformy [Design of modern concrete structures: defining principles and technological platforms.] Construction Materials. 2014. No. 3. P. 6-14. (In Russian).

3. Ostroukh A.V., Nedoseko I.V., Surkova N.E., Bulatov B.G. Automated control system for the milling unit of mineral powders plant. International Journal of Applied Engineering Research. 2016. V. 11, no. 4. P. 2625-2628.

4. Vstovsky G.V., Kolmakov A.G., Bunin I.Zh. Vvedeniye v mul'tifraktal'nuyu parametrizatsiyu struktur materialov [Introduction to the multifractal parameterization of material structures.] Moscow, SIC "Regular and chaotic dynamics", 2001. 116 p. (In Russian).

5. Korenkova S.F., Sidorenko J.V. K voprosu o fraktal'noy razmernosti nanotekhnogennogo syr'ya [To the question about fractal dimension of nanotechnological stuff.] Nanotehnologii v stroitel'stve $=$ Nanotechnologies in Construction, 2010. Vol. 2, no. 3. P. 26-32. (In Russian).

6. Mashukov N.I., Khalikov R.M., Kharaev A.M. Stabilizatsiya i modifikatsiya molekulyarnykh struktur [Stabilization and modification of molecular structures]. Saarbrucken, Palmarium Academic Publishing, 2014. 210 p. (In Russian).

7. Komokhov P. G. Zol'-gel' kak kontseptsiya nanotekhnologii tsementnogo kompozita [Sol-gel as a concept of nanotechnology of cement composite]. Construction Materials. 2006. No 9. P. 89-90. (In Russian).

8. Witten T.A., Sander L.M. Diffusion-limited aggregation. Physical Review. 1983. V. 27, no. 9. P. 5686-5697.

9. Sinitsin D.A, Salova M.S., Sultanshina E D., Ryazanova V. A. Primeneniye betona povyshennoy prochnosti pri betonirovanii fundamentnoy plity pod vysotnyy zhiloy dom v g. Ufa [The use of high-strength concrete in concreting the foundation slab under the high-rise residential building in the city of Ufa]. Materials Conf. "Actual problems of technical, natural and humanitarian sciences”. Ufa. 2016. P. 123-125. (In Russian).

10. Lesovik V.S., Chulkova I. S. Upravleniye strukturoobrazovaniyem stroitel'nykh kompozitov [Management of structure formation of building composites.] Omsk, SibADI, 2011. 420 p. (In Russian).

11. Evelson L.I., Lukutsova N.P., Nikolaenko A.N. et al. Nekotoryye prakticheskiye aspekty fraktal'nogo modelirovaniya struktury nanokompozitsionnogo materiala [Some practical aspects of fractal modeling of the structure of nanocomposite materials]. Construction Materials. 2015. No 11. P. 24-27. (In Russian).

12. Kudryavtsev P.G. Sostav i struktura poristykh termostoykikh neorganicheskikh kompozitsionnykh materialov [Composition and structure of porous heat-resistant inorganic composite materials.] Nanotehnologii v stroitel'stve = Nanotechnologies in Construction. 2018. Vol. 10, no. 4, pp. 75-100. DOI: dx.doi.org/10.15828/2075- 8545-2018-10-4-75-100. (In Russian).

13. Mukhametshin V.V., Kadyrov R.R. Vliyaniye nanodobavok na mekhanicheskiye i vodoizoliruyushchiye svoystva sostavov na osnove tsementa [Influence of nanoadditives on mechanical and isolating properties of cement-based compositions]. Nanotehnologii $\mathrm{v}$ stroitel'stve $=$ Nanotechnologies in Construction. 2017. Vol. 9, no. 6, pp. 18-36. DOI: dx.doi. org/10.15828/2075-8545-20179-6-18-36. (In Russian).

14. Vernigorova V.N., Korolev E.V., Eremkin A.I., etc. Korroziya stroitel'nykh materialov [Corrosion of building materials]. Moscow, Publishing House "Paleotype", 2007. 176 p. (In Russian).

15. Oratovska A.A., Sinitsyn D A., Galeeva L.S., Babkov V.V., Shatov A.A. Ispol'zovaniye otkhodov proizvodstva kal'tsinirovannoy sody dlya polucheniya izvest'soderzhashchikh vyazhushchikh i stroitel'nykh materialov na ikh osnove [The use waste of production of soda ash to obtain lime-containing binders and building materials on their basis]. Construction Materials. 2012. No. 2. P. 52-53. (In Russian).

16. Khalikov R. M., Ivanova O. V. Tekhnologicheskiye skhemy resheniya ekologicheskikh problem regional'nogo proizvodstva materialov [Technological schemes of solution of ecological problems of regional production of materials]. Nauka-Rastudent.ru. 2014. No. 3 (03). P. 10. (In Russian).

17. Bulatov B.G., Nedoseko I.V. Перспективы использования результатов функционирования системы автоматизации производства стеновых изделий из фосфогипса [The prospects of using the results of the operation of the system of automation of the production of wall products from phosphogypsum]. News of Kazan state university of architecture and construction. 2017. No. 1(39). P. 302-308. (In Russian).

18. Babkov V.V., Nedoseko I.V., Shayakhmetov U.S., Pechenkina T.V. Stenovyye izdeliya na osnove fosfogipsa [Wall products on the basis of phosphogypsum]. Bulletin of the Academy of Sciences RB. 2008. Vol. 13, No. 2. P. 29-30. (In Russian).

19. Houst Y.F., Bowen P., Perche F. et al. Design and function of novel superplasticizers for more durable high performance concrete (superplast project). Cement and Concrete Research. 2008. Vol. 38, no. 10. P. 1197-1209.

20. Kuzmina V.P. Modifikatsiya kompozitsionnykh materialov na osnove vyazhushchikh materialov [Modification of composite materials on the basis of binder materials.] Nanotehnologii v stroitel'stve $=$ Nanotechnologies in Construction. 2011. Vol. 3, no. 1, pp. 70-77. (In Russian). 


\section{СПИСОК ЛИТЕРАТУРЫ}

1. Фиговский О.Л., Бейлин Д.А., Пономарев А.Н. Успехи применения нанотехнологий в строительных материалах // Нанотехнологии в строительстве. - 2012. - Том 4, № 3. - C. 6-21. - URL: http://nanobuild.ru/ru_RU (дата обращения: 17 октября 2018 г.)

2. Баженов Ю.М., Чернышов Е.М., Коротких Д.Н. Конструирование структур современных бетонов: определяющие принципы и технологические платформы // Строительные материалы. - 2014. - № 3. - С. 6-14.

3. Ostroukh A.V., Nedoseko I.V., Surkova N.E., Bulatov B.G. Automated control system for the milling unit of mineral powders plant // International Journal of Applied Engineering Research. - 2016. - V. 11, N.4. - P. 2625-2628.

4. Встовский Г.В., Колмаков А.Г., Бунин И.Ж. Введение в мультифрактальную параметризацию структур материалов. - М.: НИЦ «Регулярная и хаотическая динамика», 2001. - 116 с.

5. Коренькова С.Ф., Сидоренко Ю.В. К вопросу о фрактальной размерности нанотехногенного сырья // Нанотехнологии в строительстве. - 2010. - Том 2, № 3. - С. 26-32. - URL: http://nanobuild.ru/ru_RU (дата обращения: 18 октября 2018 г.)

6. Машуков Н.И., Халиков Р.М., Хараев А.М. Стабилизация и модификация молекулярных структур. - Saarbrucken: Palmarium Academic Publishing, 2014. - 210 c.

7. Комохов П.Г. Золь-гель как концепция нанотехнологии цементного композита // Строительные материалы. 2006. - № 9. - C. 89-90.

8. Witten T.A., Sander L.M. Diffusion-limited aggregation // Physical Review. - 1983. - V. 27, N. 9. - P. 5686-5697.

9. Синицин Д.А., Салова М.С., Султаншина Э.Д., Рязанова В.А. Применение бетона повышенной прочности при бетонировании фундаментной плиты под высотный жилой дом в г. Уфа // Материалы Международ. конф. «Актуальные проблемы технических, естественных и гуманитарных наук». - Уфа: УГНТУ, 2016. - С. 123-125.

10. Лесовик В.С., Чулкова И.С. Управление структурообразованием строительных композитов. - Омск: СибАДИ, 2011. $-420 \mathrm{c}$.

11. Евельсон Л.И., Лукутцова Н.П., Николаенко А.Н. и др. Некоторые практические аспекты фрактального моделирования структуры нанокомпозиционного материала // Строительные материалы. - 2015. - № 11. - С. $24-27$.

12. Кудрявцев П.Г. Состав и структура пористых термостойких неорганических композиционных материалов // Нанотехнологии в строительстве. - 2018. - Том 10, № 4. - C. 75-100. - DOI: dx.doi.org/10.15828/2075-8545-2018-10-4-75-100.

13. Мухаметшин В.В., Кадыров Р.Р. Влияние нанодобавок на механические и водоизолирующие свойства составов на основе цемента // Нанотехнологии в строительстве. - 2017. - Том 9, № 6. - C. 18-36. - DOI: dx.doi.org/10.15828/20758545-2017-9-6-18-36.

14. Вернигорова В.Н., Королев Е.В., Еремкин А.И. и др. Коррозия строительных материалов. - М.: Палеотип, 2007. $-176 \mathrm{c}$.

15. Оратовская А.А., Синицин Д.А., Галеева Л.Ш., Бабков В.В., Шатов А.А. Использование отходов производства кальцинированной соды для получения известьсодержащих вяжущих и строительных материалов на их основе // Строительные материалы. - 2012. - № 2. - С. 52-53.

16. Халиков Р.М., Иванова О.В. Технологические схемы решения экологических проблем регионального производства материалов // Nauka-Rastudent.ru. - 2014. - № 3(03). - C. 10.

17. Булатов Б.Г., Недосеко И.В. Перспективы использования результатов функционирования системы автоматизации производства стеновых изделий из фосфогипса // Известия Казанского государственного архитектурно-строительного университета. - 2017. - № 1 (39). - С. 302-308.

18. Бабков В.В., Недосеко И.В., Шаяхметов У.Ш., Печенкина Т.В. Стеновые изделия на основе фосфогипса // Вестник АН РБ. - 2008. - Т. 13, № 2. - С. 29-30.

19. Houst Y.F., Bowen P., Perche F. et al. Design and function of novel superplasticizers for more durable high performance concrete (superplast project) // Cement and Concrete Research. - 2008. - V. 38, No. 10. - P. 1197-1209.

20. Кузьмина В.П. Модификация композиционных материалов на основе вяжущих материалов // Нанотехнологии в строительстве. - 2011. - Том 3, № 1. - C. 70-77. URL: http://nanobuild.ru/ru_RU (дата обращения: 19 октября 2018 г.) . 


\section{INFORMATION ABOUT THE AUTHORS}

Sinitsin Dmitry Aleksandrovich, Ph.D. of Engineering, Ufa State Petroleum Technological University; Mendeleev st., 195, Ufa, Bashkortostan Republic, Russia, 450080, e-mail: d4013438@yandex.ru;

Khalikov Rauf Muzagitovich, Ph.D. of Chemistry, Ufa State Petroleum Technological University; Mendeleev st., 195, Ufa, Bashkortostan Republic, Russia, 450080, e-mail: rauf_khalikov@mail.ru;

Bulatov Bulat Galievich, Senior teacher, Bashkir State Agrarian University; 50-letiya Oktyabrya st., 34, Ufa, Bashkortostan Republic, Russia, 450001, e-mail: bfd82@mail.ru;

Galitskov Konstantin Stanislavovich, Ph.D. of Engineering, Samara State Technical University; Molodogvardeyskaya st., 244, Samara, Russia, 443001, e-mail: ksgal@yandex.ru;

Nedoseko Igor Vadimovich, Doctor of Engineering, Professor, Ufa State Petroleum Technological University; Mendeleev st., 195, Ufa, Bashkortostan Republic, Russia, 450080, e-mail: nedoseko1964@mail.ru

\section{ИНФОРМАЦИЯ ОБ АВТОРАХ}

Синицин Дмитрий Александрович, к.Т.н., доц. каф. «Строительные конструкции», ФГБОУ ВО «Уфимский государственный нефтяной технический университет»; ул. Менделеева, 195, г. Уфа, Республика Башкортостан, Россия, 450080, d4013438@yandex.ru;

Халиков Рауф Музагитович, к.Х.н., доц. каф. «Строительные конструкции», ФГБОУ ВО «Уфимский государственный нефтяной технический университет»; ул. Менделеева, 195, г. Уфа, Республика Башкортостан, Россия, 450080, rauf_khalikov@mail.ru;

Булатов Булат Галиевич, ст. преп. каф. «Природообустройства, строительства и гидравлики», ФГБОУ ВО «Башкирский государственный аграрный университет»; ул. 50-летия Октября, 34, г. Уфа, Республика Башкортостан, Россия, 450001, bfd82@mail.ru;

Галицков Константин Станиславович, к.т.н., доц. каф. «Механизация, автоматизация и энергоснабжение строительства», ФГБОУ ВО «Самарский государственный технический университет»; ул. Молодогвардейская, 244, г. Самара, Россия, 443001, ksgal@yandex.ru;

Недосеко Игорь Вадимович, д.Т.н., проф. каф. «Строительные конструкции», ФГБОУ ВО «Уфимский государственный нефтяной технический университет»; ул. Менделеева, 195, г. Уфа, Республика Башкортостан, Россия, 450080, nedoseko1964@mail.ru 